\title{
PERANCANGAN ENTERPRISE RESOURCE PLANNING (ERP) UNTUK MENUNJANG FUNGSI BISNIS DI PT. SELECTRIX INDONESIA
}

\author{
Rosmalina $^{\text {1) }}$, Asep Muhammad Indra ${ }^{2)}$ \\ Prodi. Sistem Informasi ${ }^{1)}$ 2) \\ Universitas Bale Bandung ${ }^{1)}$, Universitas Sangga Buana YPKP ${ }^{2)}$ \\ Rosmalina82@yahoo.com ${ }^{1)}$, amip.khan@gmail.com ${ }^{2)}$
}

\begin{abstract}
ABSTRAK
Perancangan ERP (Enterprise Resource Planning) di PT. Selectrix Indonesia menjadi langkah awal dalam menerapkan strategi integrasi seluruh aspek kegiatan operasional perusahaan baik internal maupun eksternal. Persaingan bisnis yang semakin pesat dan ketat menuntut perusahaan untuk terus meningkatkan kinerja, memiliki keunggulan dalam kompetisi dan daya saing. Penerapan ERP tidaklah mudah, karena menyatukan seluruh proses bisnis dan fungsi bisnis di perusahaan dalam sebuah sistem yang utuh dan saling berkaitan satu sama lainnya. Sehingga diperlukannya suatu perancangan ERP yang baik dan tepat sesuai dengan proses bisnis dan kebutuhan perusahaan, karena tidak sedikit berbagai implementasi ERP oleh perusahaan-perusahaan di Indonesia yang mengalami kegagalan baik disebabkan oleh over budget, over time dalam pengerjaan proyek, kinerja sistem yang kurang dan keuntungan yang tidak sesuai harapan (Dantes \& Hasibuan 2011). Perancangan ERP perlu dilakukan secara matang, melihat berbagai fungsi bisnis yang ada dalam perusahaan seperti fungsi bisnis tata kelola karyawan (human resource), tata kelola keuangan (financial), tata kelola persediaan (inventory), tata kelola distribusi (distribution), tata kelola penjualan (sales) dan fungsi-fungsi bisnis lainnya yang ada di perusahaan. Output dari penelitian ini berupa cetak biru (blueprint) sebuah perancangan ERP yang tepat untuk di terapkan di PT. Selectrix Indonesia didasarkan proses bisnis dan kebutuhan perusahaan.
\end{abstract}

Kata Kunci : Enterprise Resource Planning, Bisnis Proses Perusahaan, Perancangan Sistem, Operasional Perusahaan

\section{PENDAhUluan}

Banyak perusahaan di Indonesia baik bidang manufaktur ataupun jasa sudah menerapkan sistem informasi dalam kegiatan operasional bisnisnya. Namun dari sekian banyak perusahaan tersebut, hanya beberapa perusahaan yang sudah menerapkan ERP (Enterprise Resource Planning) dengan baik yang ditunjang dengan perancangan dan perencanaan yang baik sehingga dapat berperan mengintegrasikan dan mengotomasikan proses bisnis yang berhubungan dengan aspek operasi, produksi maupun distribusi di perusahaan bersangkutan.

Kebanyakan perusahaan di Indonesia, hanya menerapkan sistem informasi terhadap salah satu atau beberapa fungsi bisnis yang hanya dilihat dari sudut pandang fungsi bisnis tertentu tidak melihat bagaimana hubungannya dengan fungsi bisnis lain. Dimana akan terlihat suatu perbedaan data dan informasi yang dihasilkan dari masing-masing fungsi bisnis untuk sebuah permasalahan bisnis yang saling berkaitan, sehingga perlu dilakukan diskusi dan penyamaan persepsi dari setiap departemen dan divisi yang memiliki perbedaan data dan informasi yang dihasilkan.

PT. SELECTRIX INDONESIA merupakan perusahaan Penanam Modal Asing (PMA) Australia yang bergerak di bidang manufaktur pembuatan kunci dan aksesoris panel dan mempunyai kantor pusat di Australia. Perusahaan ini berdiri pada tahun 2005, sebagian besar produk di ekspor ke beberapa negara terutama negara Australia dan New Zeland. Dengan bisnis yang mendunia menuntut perusahaan menerapkan ERP sebagai penunjang kegiatan operasional baik bersifat internal maupun eksternal.

Sebagai langkah awal penerapan ERP di PT. SELECTRIX INDONESIA diperlukannya suatu perancangan ERP yang matang supaya saat penerapan ERP tidak mengalami over time, 
over budget, memiliki kinerja yang baik dan sesuai harapan dan kebutuhan perusahaan untuk tata kelola karyawan, keuangan, persediaan, distribusi dan penjualan serta fungsi bisnis lainnya yang ada di perusahaan yang terintegrasi secara utuh.

Berdasarkan hasil analisis sistem saat ini, kebutuhan akan Enterprise Resource Planning (ERP) yang paling diperlukan adalah HRD/GA dikarenakan saat ini proses bisnis HRD/GA yaitu Pengelolaan kegiatan rekruitmen dan pengelolaan administrasi karyawan belum menggunakan sistem informasi yang terintegrasi dengan fungsi bisnis lain dan masih dilakukan secara manual dengan menggunakan aplikasi one processing, berbeda halnya dengan fungsi bisnis lain seperti PPIC, Purchasing, dan Produksi sudah menggunakan sistem informasi yang terintegrasi satu sama lainnya.

Tujuan dari penelitian ini adalah untuk membuat perancangan ERP khususnya pada departemen sumber daya manusia yang mendukung penerapan ERP dalam menunjang fungsi bisnis perusahaan

\section{LANDASAN TEORI}

\section{Definisi Sistem}

Menurut Al-Bahra Ladjamudin (2005), dalam bukunya menyatakan terdapat dua kelompok pendekatan sistem, yaitu sistem yang lebih menekankan pada prodesur dan elemenya. Prosedur di definisikan sebagai suatu urutanurutan yang tepat dari tahapan-tahapan intruksi yang menerangkan apa yang harus dikerjakan, siapa yang mengerjakan, kapan dikerjakan dan bagaimana mengerjakannya (Gerald. J., 1991).

\section{Analisis Sistem}

Menurut Rosa A. S dan M. Shalahuddin (2013), yang dimaksud analisis sistem adalah mendefinisikan kebutuhan terkait sistem yang akan dikembangkan. Kegiatan analisis sistem adalah kegiatan untuk melihat sistem yang sudah berjalan, melihat bagian mana yang bagus dan tidak bagus dan kemudian mendokumentasikan kebutuhan yang akan dipenuhi dalam sistem yang baru

\section{Definisi Informasi}

Menurut Al-Bahra Bin Ladjamudin (2005) dalam menganalisis dan merencanakan perancangan suatu sistem harus mengerti terlebih dahulu komponen-komponen yang ada didalam sistem tersebut. Darimana data dan informasi tersebut diperoleh dan kemana hasil pengolahan data dan informasi tersebut diperlukan.

\section{Definisi Sistem Informasi}

Menurut Leitch (2004), sistem informasi adalah suatu sistem di dalam suatu organisasi yang mempertemukan kebutuhan pengolahan transaksi harian, mendukung operasi, bersifat manajerial dan kegiatan strategi dari suatu organisasi dan menyediakan pihak luar tertentu dengan laporan-laporan yang diperlukan

\section{Konsep dan Arsitektur ERP (Enterprise Resource Planning)}

ERP adalah tulang punggung teknologi dari $e$ business, sebuah kerangka kerja transaksi keseluruhan perusahaan dengan berbagai hubungan ke pemrosesan pesanan, penjualan, manajemen, dan pengendalian persediaan, perencanaan produksi dan distribusi, serta keuangan.

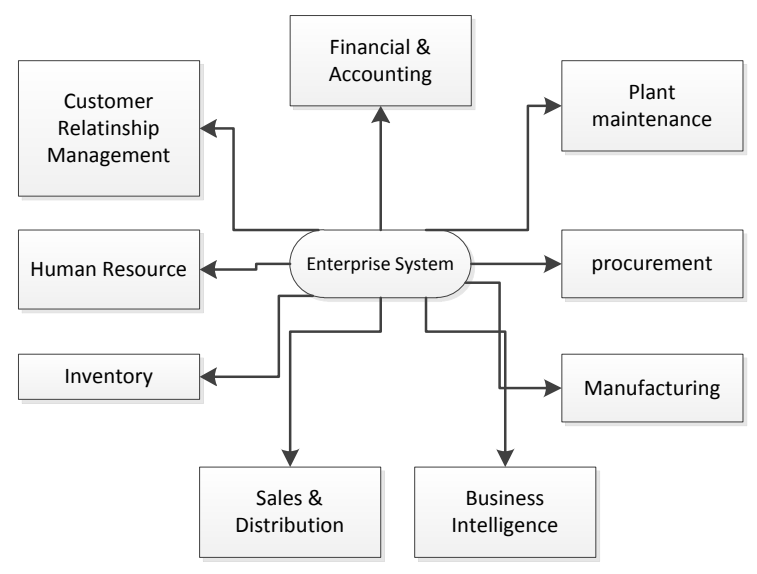

Gambar 1 konsep sistem ERP

\section{Unified Modelling Language}

Unified Modeling Language (UML) adalah bahasa atau alat bantu untuk visualisasi, spesifikasi, kontruksi, dan dokumentasi artifakartifak perangkat lunak yang dibuat dengan menggunakan konsep pendekatan berorientasi objek (Badriah, Tesy).

\section{Database}

Menurut Fathansyah (2007), basis data terdiri atas dua kata, yaitu basis dan data. Basis kurang lebih dapat diartikan sebagai markas atau gudang, tempat bersarang/berkumpul. 


\section{Definisi ERD}

Menurut Ladjamudin

(2013:142)

menjelaskan bahwa "ERD adalah suatu model jaringan yang menggunakan susunan data yang disimpan dalam sistem secara abstrak". ERD ini berada dengan DFD yang merupakan suatu model jaringan fungsi yang akan dilaksanakan oleh sistem, sedangkan ERD merupakan model jaringan data yang menekankan pada strukturstruktur dan relationship data.

\section{METODE PENELTIAN}

Rancangan penelitian didasarkan pada tujuan dan metodologi perancangan ERP yang didasari perancangan Sistem Informasi, adapun rancangan penelitian ini antara lain :

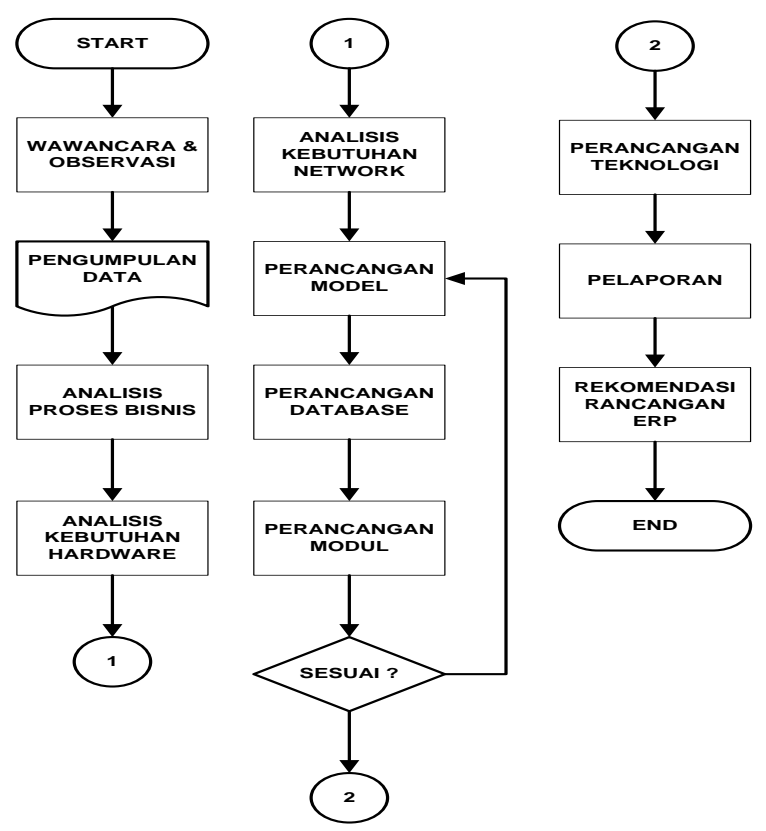

Gambar 2 Rancangan Penelitian

\section{PEMBAHASAN}

\section{Profil Perusahaan}

Industri selectrix dimulai sebagai sebuah bisnis keluarga kecil di Preston pada tahun 1978. Filosofi kami sangat bias karyawan, yang telah menghasilkan komunitas selectrix rajutan yang sangat dekat dengan anggota yang setia, berbakat, dan pekerja keras. Banyak karyawan telah bekerja di perusahaan selama periode 10 hingga 20 tahun dan kemudian ada anak lakilaki/perempuan yang juga telah memulai, membawa generasi lain dengan ide-ide baru yang segar.

\section{Analisis Proses Bisnis}

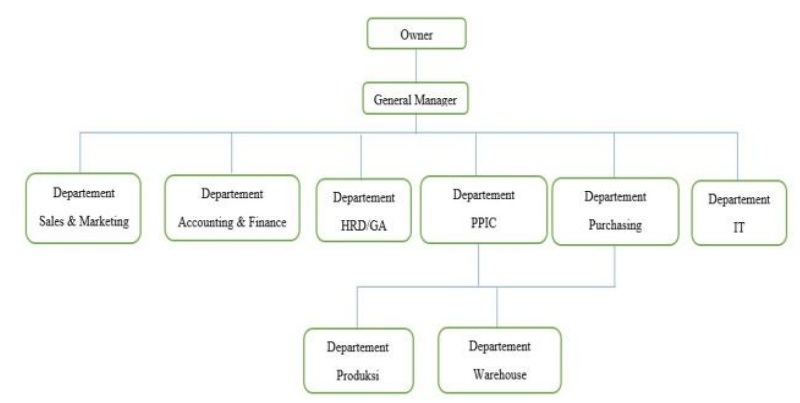

Gambar 3 Struktur Organisasi PT. Selectrix Indonesia

\section{Analisis Kebutuhan ERP}

a. Analisis Sistem Saat Ini

Adapun proses bisnis yang berjalan di departemen HRD/GA terkait tata kelola sumber daya manusia di perusahaan, antara lain : HRD mengelola kegiatan rekrutmen yang diajukan oleh Divisi lain dimulai dari proses pencarian kandidat, undangan interview, pengisian biodata pelamar, interview user, psikotest dan test divisi, dan peresmian rekrutmen. HRD mengelola administrasi karyawan mulai dari pengelolaan biodata karyawan, divisi, jabatan dan kepangkatan, jaminan sosial tenaga kerja, kehadiran dan payroll.

\section{b. Evaluasi Sistem Yang Sedang Berjalan}

Evaluasi Sistem Yang Sedang Berjalan terkait fungsi bisnis yang dilakukan di PT. Selectrix, antara lain : Dari keseluruhan fungsi bisnis yang ada di PT. Selectrix hanya HRD/GA yang belum terintegrasi dengan fungsi bisnis lain. Concern perancangan Enterprise Resource Planning (ERP) di PT. Selectrix berpusat pada fungsi bisnis HRD/GA terkait tata kelola sumber daya manusia di perusahaan. Proses tata kelola sumber daya manusia di PT. Selectrix masih dilakukan manual menggunakan aplikasi one processing.

\section{c. Analisis Pemecahan Masalah}

Berdasarkan analisis sistem yang sedang berjalan dan evaluasi sistem yang berjalan, dihasilkan analisis pemecahan masalah terkait fungsi bisnis HRD/GA terkait tata kelola sumber daya manusia di PT. Selectrix antara lain :

1) Diperlukannya sistem informasi yang mengelola biodata karyawan perusahaan. 
2) Diperlukannya sistem informasi yang mengelola divisi perusahaan.

3) Diperlukannya sistem informasi yang mengelola jabatan dan kepangkatan karyawan perusahaan.

4) Diperlukannya sistem informasi yang mengelola jaminan sosial tenaga kerja.

5) Diperlukannya sistem informasi yang mengelola kehadiran karyawan.

6) Diperlukannya sistem informasi yang mengelola payroll karyawan

\section{Perancangan Enterprise Resource Planning}

Perancangan merupakan tahapan yang dilakukan setelah tahapan analisis dilakukan, adapun perancangan Enterprise Resource Planning (ERP) antara lain perancangan model sistem dan perancangan basis data sistem informasi

\section{Perancangan Model}

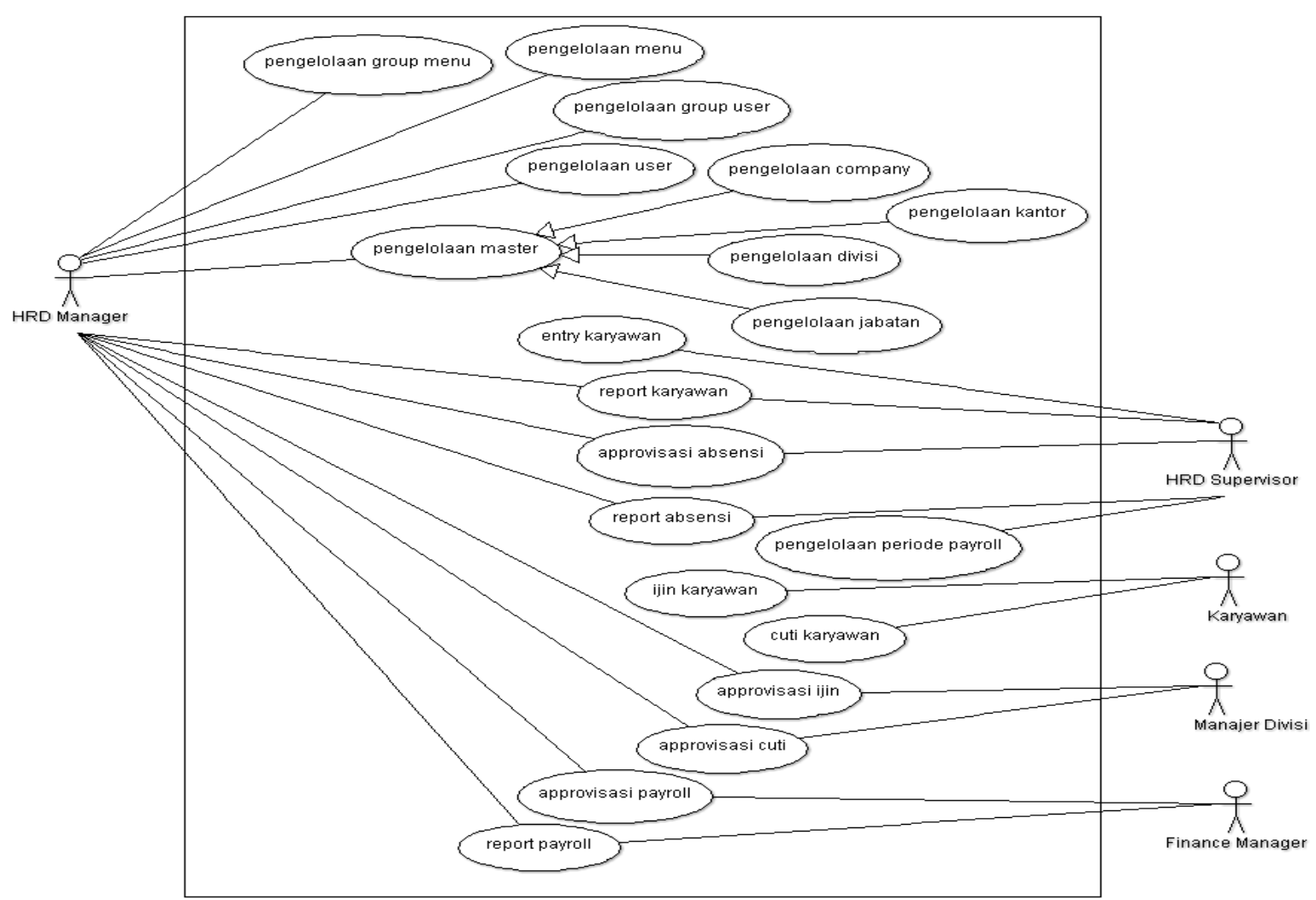

Gambar 4 Use Case Diagram ERP untuk Tata Kelola Sumber Daya Manusia di PT. Selectrix

Skenario Use Case Pengelolaan Group Menu

Tabel 1 Skenario Use Case Pengelolaan Group Menu

\begin{tabular}{|c|c|c|}
\hline \multicolumn{3}{|c|}{ Identifikasi } \\
\hline Nama & \multicolumn{2}{|c|}{ Kelola Group Menu } \\
\hline Tujuan & \multicolumn{2}{|c|}{ Untuk melakukan proses pengelolaan group menu } \\
\hline \multicolumn{3}{|c|}{ Deskripsi } \\
\hline & Aktor & HRD Manajer \\
\hline & Skenario Utama & Skenario Utama \\
\hline & Kondisi Awal & - \\
\hline & Aksi Aktor & Reaksi Sistem \\
\hline 1. Klik n & utama akses & 2. Sistem menampilkan menu akses \\
\hline 3. Klik n & & 4. Sistem menampilkan menu daftar group \\
\hline
\end{tabular}




\begin{tabular}{|c|c|}
\hline & menu dan entry group menu \\
\hline 5. $\quad$ Pilih entry group menu & $\begin{array}{l}\text { 6. Sistem menampilkan halaman entry } \\
\text { group menu }\end{array}$ \\
\hline $\begin{array}{l}\text { 7. Lakukan input group menu, kemudian klik } \\
\text { tombol save }\end{array}$ & $\begin{array}{l}\text { 8. Sistem mengeluarkan message box data } \\
\text { telah disimpan ke database }\end{array}$ \\
\hline Kondisi Akhir & Group menu tersimpan \\
\hline
\end{tabular}

Activity Diagram Pengelolaan Group Menu

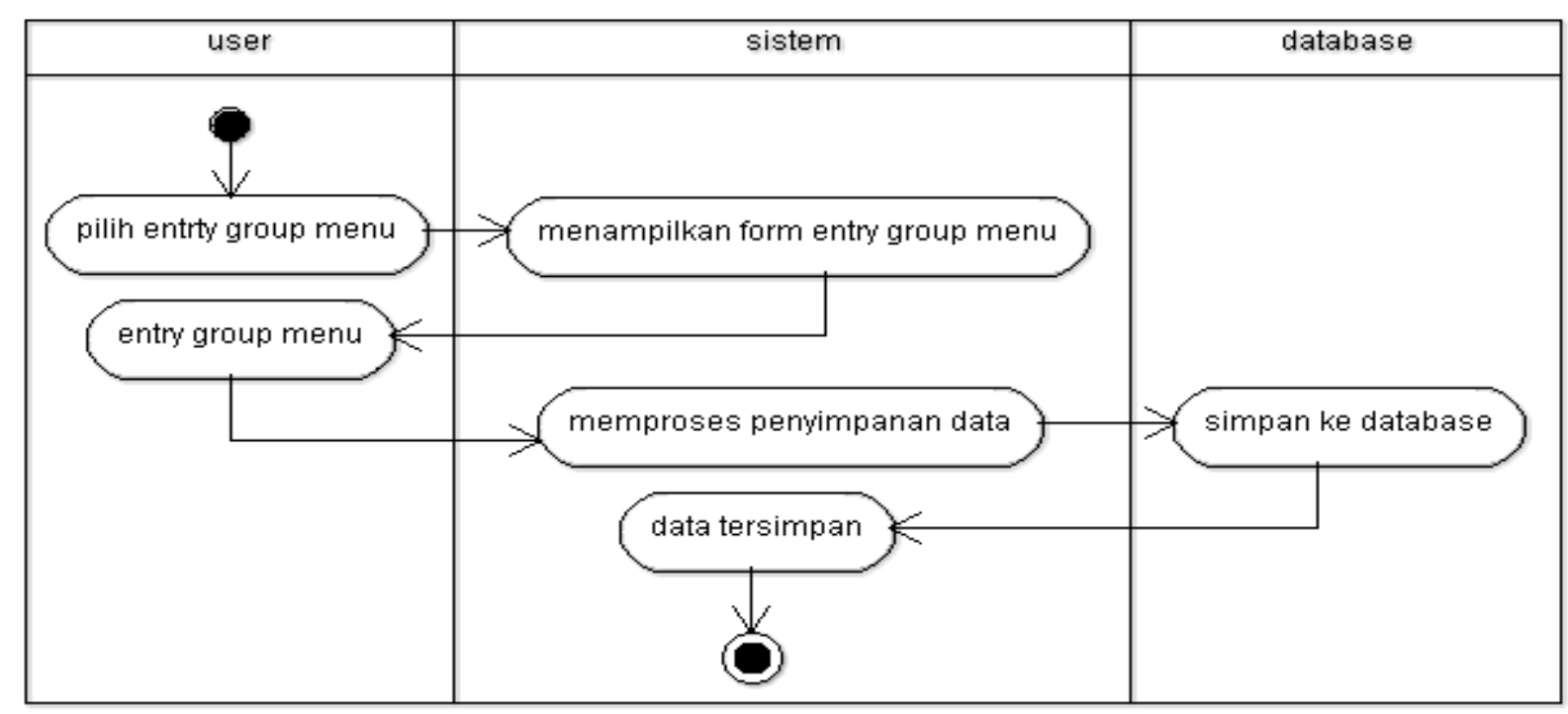

Gambar 5 Activity Diagram Pengelolaan Group Menu

\section{Perancangan Basis Data ERP}

1. Perancangan ERP

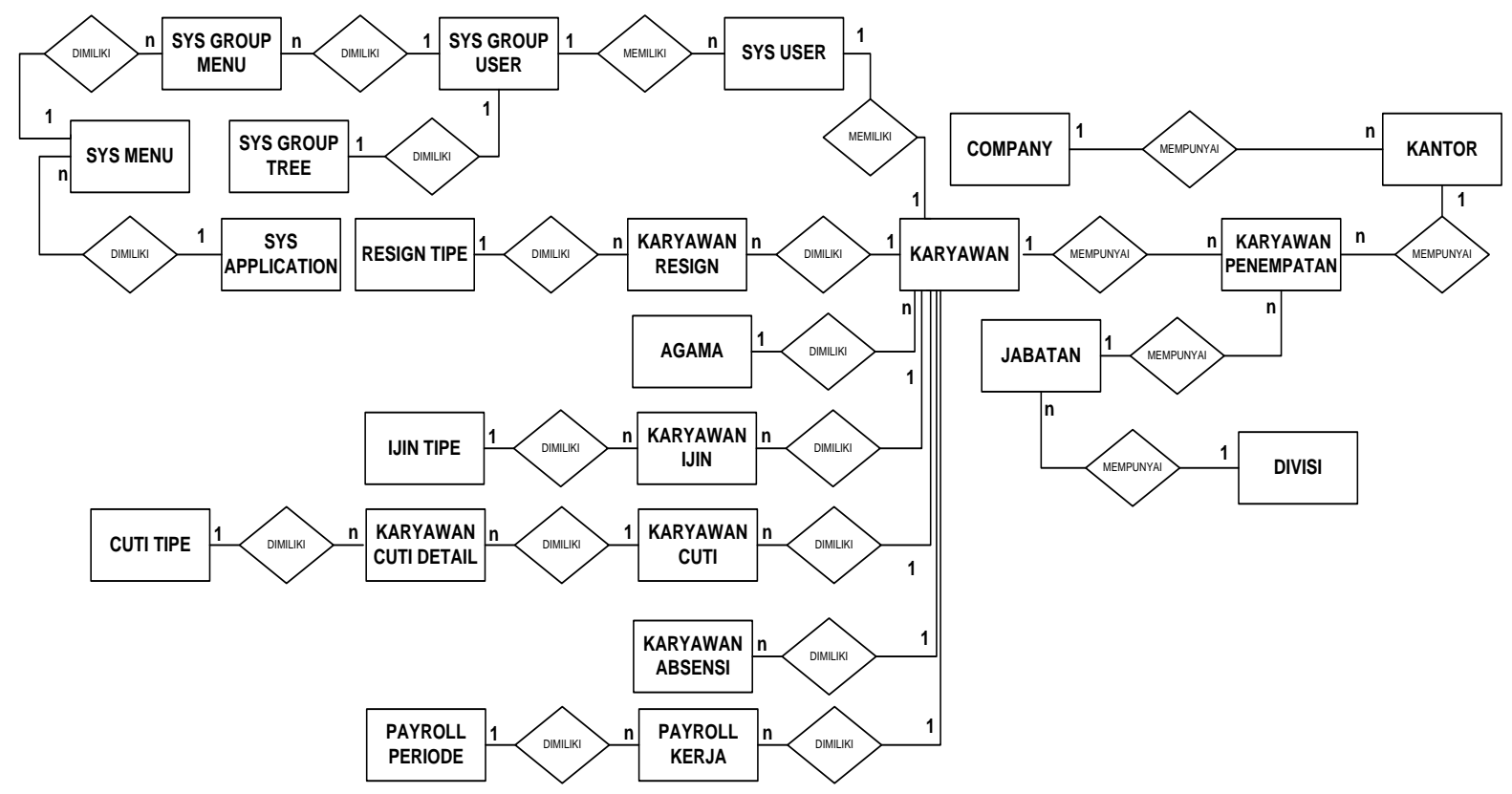

Gambar 6 Entity Relationship Diagram

2. Relasi Tabel 


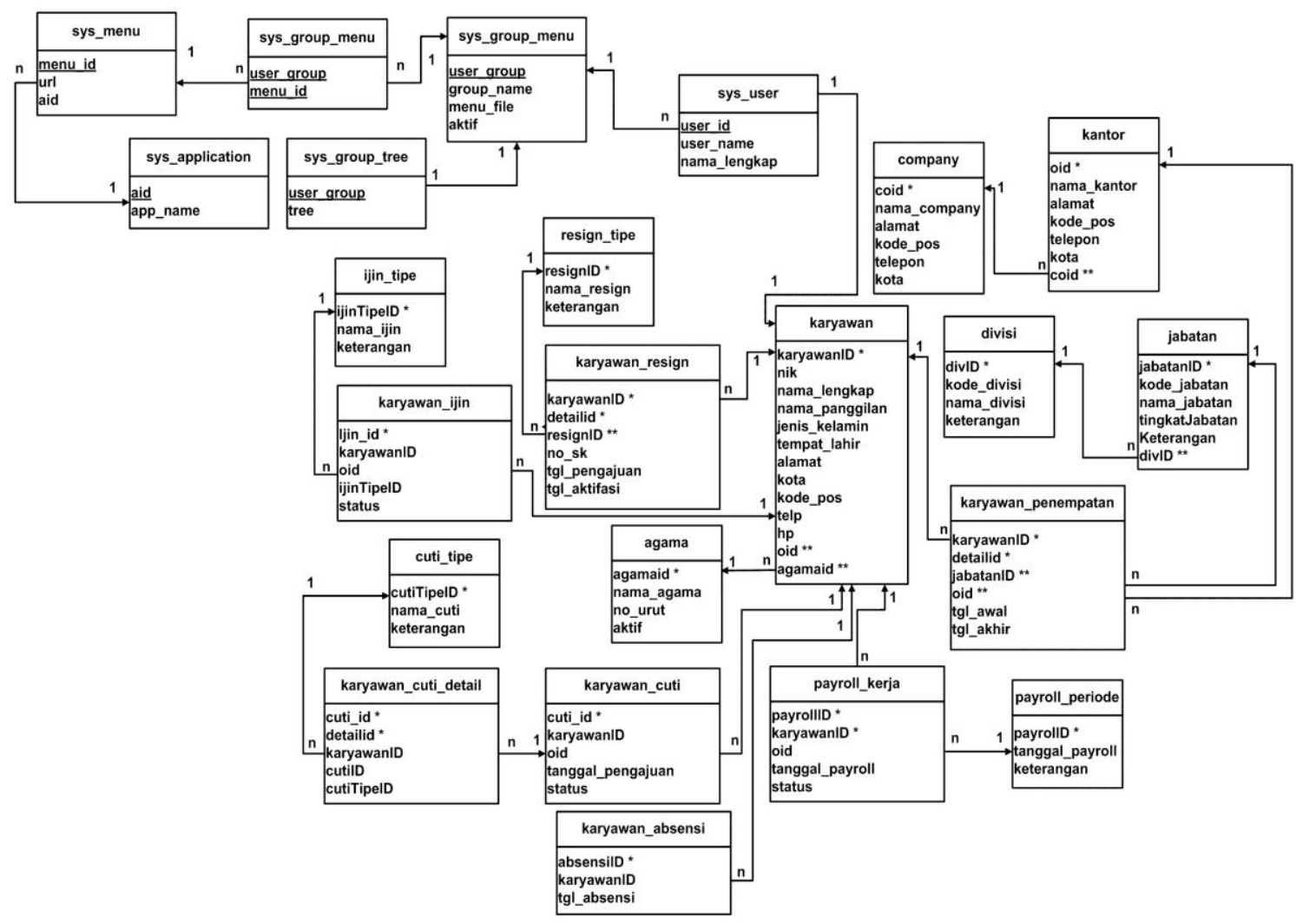

Gambar 7 Relasi Tabel

3. Deskripsi Tabel Sistem Informasi

Company

Tabel 2 Deskripsi Tabel untuk company

\begin{tabular}{|c|c|c|c|}
\hline Field & Deskripsi & Tipe Data & Ukuran \\
\hline coid* & id company dan primary key & char & 5 \\
\hline nama_company & nama company & varchar & 100 \\
\hline alamat & alamat company & varchar & 100 \\
\hline kode_pos & kode pos company & varchar & 10 \\
\hline telepon & telepon company & varchar & 15 \\
\hline kota & kota company & varchar & 100 \\
\hline bankID & bank company & char & 5 \\
\hline no_rek & nomor rekening company & varchar & 30 \\
\hline nama_rekening & atas nama rekening company & varchar & 100 \\
\hline createdBy & user input company & datetime & \\
\hline createdDate & tanggal input company & varchar & 11 \\
\hline modifiedBy & user modifiy company & datetime & \\
\hline modifiedDate & tanggal modify company & varchar & 11 \\
\hline deletedBy & user delete company & datetime & \\
\hline deletedDate & tanggal delete company & enum & 'y','n' \\
\hline aktif & status aktif company & date & \\
\hline tgl_aktif & Date & date & \\
\hline tgl_inaktif & Date & & \\
\hline
\end{tabular}


Tabel 3 Deskripsi Tabel untuk jabatan

\begin{tabular}{|c|c|c|c|}
\hline Field & Deskripsi & Tipe Data & Ukuran \\
\hline jabatanID* & id jabatan dan primary key & char & 6 \\
\hline kode_jabatan & kode jabatan & varchar & 20 \\
\hline nama_jabatan & nama jabatan & varchar & 120 \\
\hline divID & id divisi jabatan & char & 7 \\
\hline tingkatJabatan & tingkatan jabatan & enum & \\
\hline fungsiTugas & fungsi tugas jabatan & enum & \\
\hline cost_centerID & id cost center & char & 5 \\
\hline keterangan & keterangan jabatan & varchar & 255 \\
\hline createdBy & user input jabatan & datetime & 11 \\
\hline createdDate & tanggal input jabatan & varchar & 11 \\
\hline modifiedBy & user modifiy jabatan & datetime & \\
\hline modifiedDate & tanggal modify jabatan & varchar & 11 \\
\hline deletedBy & user delete jabatan & datetime & \\
\hline deletedDate & tanggal delete jabatan & enum & 'y','n' \\
\hline aktif & status aktif jabatan &
\end{tabular}

Tabel 4 Deskripsi Tabel untuk karyawan

\begin{tabular}{|c|c|c|c|}
\hline Field & Deskripsi & Tipe Data & Ukuran \\
\hline karyawanID* & id karyawan dan primary key & char & 14 \\
\hline nik & nomor induk karyawan & varchar & 11 \\
\hline nama_lengkap & nama lengkap karyawan & varchar & 150 \\
\hline nama_panggilan & nama panggilan karyawan & varchar & 50 \\
\hline jenis_kelamin & jenis kelamin karyawan & enum & 'L','P' \\
\hline tempat_lahir & tempat lahir karyawan & varchar & 100 \\
\hline tanggal_lahir & tanggal lahir karyawan & date & \\
\hline alamat & alamat karyawan & varchar & 150 \\
\hline kota & kota alamat karyawan & varchar & 100 \\
\hline kode_pos & kode pos alamat karyawan & char & 5 \\
\hline telp & nomor telepon karyawan & varchar & 13 \\
\hline $\mathrm{hp}$ & nomor hp karyawan & varchar & 15 \\
\hline ktp & nomor ktp karyawan & varchar & 50 \\
\hline no_jamsostek & nomor jamsostek karyawan & varchar & 50 \\
\hline no_npwp & nomor npwp karyawan & varchar & 50 \\
\hline email & email karyawan & varchar & 100 \\
\hline agamaid & kode agama karyawan & char & 2 \\
\hline status_marital & status marital karyawan & enum & \\
\hline golongan_darah & golongan darah karyawan & enum & 'O','A','B','AB' \\
\hline gelar_pendidikan & gelar pendidikan karyawan & varchar & 50 \\
\hline pendidikan_terakhir & pendidikan terakhir karyawan & enum & \\
\hline jurusan & jurusan pendidikan karyawan & varchar & 50 \\
\hline no_ijazah & nomor ijazah karyawan & varchar & 25 \\
\hline tgl_masuk & tanggal masuk karyawan & date & \\
\hline bankID & id bank karyawan & char & 5 \\
\hline no_rekening & nomor rekening karyawan & varchar & 100 \\
\hline nama_rekening & atas nama rekening karyawan & varchar & 100 \\
\hline$\overline{\mathrm{cV}}$ & status cv karyawan & enum & 'y','n' \\
\hline createdBy & user input karyawan & varchar & 11 \\
\hline createdDate & tanggal input karyawan & datetime & \\
\hline modifiedBy & user modifiy karyawan & varchar & 11 \\
\hline modifiedDate & tanggal modify karyawan & datetime & \\
\hline
\end{tabular}




\begin{tabular}{|c|c|c|c|}
\hline deletedBy & user delete karyawan & varchar & 11 \\
\hline deletedDate & tanggal delete karyawan & datetime & \\
\hline status & status karyawan & enum & 'y','n' \\
\hline status_resign & status resign karyawan & enum & 'y','n' \\
\hline
\end{tabular}

payroll_informasi

Tabel 5 Deskripsi Tabel untuk payroll_informasi

\begin{tabular}{|c|c|c|c|}
\hline Field & Deskripsi & Tipe Data & Ukuran \\
\hline payrollID* & id payroll dan primary key & char & 8 \\
\hline karyawanID* & id karyawan dan primary key & char & 14 \\
\hline jabatanID & id jabatan & char & 6 \\
\hline cost_centerID & id cost center & char & 5 \\
\hline oid & id kantor payroll & char & 5 \\
\hline jumlah_masuk & jumlah masuk & int & 2 \\
\hline jumlah_dinas & jumlah dinas & int & 2 \\
\hline jumlah_sakit & jumlah sakit & int & 2 \\
\hline jumlah_ijin & jumlah ijin & int & 2 \\
\hline jumlah_alpa & jumlah alpa & int & 2 \\
\hline jumlah_resign & jumlah resign & int & 2 \\
\hline jumlah_baru & jumlah baru & int & 2 \\
\hline jumlah_kehadiran_standar & jumlah kehadiranstandar & int & 2 \\
\hline nilai_gaji_pokok & nilai gaji pokok & decimal & 10,2 \\
\hline nilai_tunjangan_kedinasan & nilai tunjangan kedinasan & decimal & 10,2 \\
\hline nilai_tunjangan_jabatan & nilai tunjangan jabatan & decimal & 10,2 \\
\hline nilai_tunjangan_khusus & nilai tunjangan khusus & decimal & 10,2 \\
\hline nilai_pinjaman & nilai pinjaman & decimal & 10,2 \\
\hline nilai_jamsostek_perusahaan & nilai jamsostek perusahaan & decimal & 10,2 \\
\hline nilai_bpjs_perusahaan & nilai bpjs perusahaan & decimal & 10,2 \\
\hline nilai_pensiun_perusahaan & nilai pensiun perusahaan & decimal & 10,2 \\
\hline nilai_gaji_brutto & nilai gaji brutto & decimal & 10,2 \\
\hline nilai_gaji_netto & nilai gaji netto & decimal & 10,2 \\
\hline nilai_umr & nilai umr & decimal & 10,2 \\
\hline transfer_tunai & status pembayaran payroll & enum & 'y','n' \\
\hline acc_pending & status acc payroll & enum & ‘y','n' \\
\hline createdBy & user input payroll karyawan & varchar & 11 \\
\hline createdDate & tanggal input payroll karyawan & datetime & \\
\hline modifiedBy & user modifiy payroll karyawan & varchar & 11 \\
\hline modifiedDate & tanggal payroll activity karyawan & datetime & \\
\hline deletedBy & user delete payroll karyawan & varchar & 11 \\
\hline deletedDate & tanggal delete payroll karyawan & datetime & \\
\hline status & status payroll karyawan & enum & 'y','n' \\
\hline
\end{tabular}

\section{Spesifikasi Kebutuhan Hardware}

Dalam pengoperasian sistem ini perlu didukung oleh perangkat keras (harware) yang memadai. Dibawah ini merupakan spesifikasi minimum perangkat keras (harware) yang digunakan:

a. Personal Computer (PC) b. Processor : Intel $₫$ Xeon $₫$ X3430 @2,340 GHZ

c. Memory : $2048 \mathrm{MB}$

d. VGA : NVIDIA Geforce 8400DS 1229MB

e. HDD : Samsung HE253GJ 250MB

f. Monitor : Compact W185Q wide LCD monitor

g. Keyboard dan Mouse : Dell

Spesifikasi Kebutuhan Perangkat Lunak 
Selain perangkat keras (harware) yang digunakan, diperlukan juga perangkat lunak (software) untuk menunjang sistem ini, dan perangkat lunak (software) yang digunakan diantaranya :

a. Sistem operasi Windows 7 Ultimate 32-bit

b. Sistem ERP (Enterprise Resource Planning)

\section{RENCANA TAHAPAN BERIKUTNYA}

Rencana tahapan berikutnya setelah dirancangnya Enterprise Resource Planning (ERP), antara lain :

1. Melakukan proses perancangan ERP lebih lanjut terutama untuk fungsi bisnis HRD/GA terkait tata kelola sumber daya manusia jika kebutuhan sistem perusahaan lebih berkembang, sebagai contoh adanya kebutuhan dalam proses penilaian karyawan Key Performance Indicator (KPI).

2. Melakukan proses perancangan ERP untuk fungsi bisnis lain yang diperlukan setelah dirancangnya ERP untuk fungsi bisnis $\mathrm{HRD} / \mathrm{GA}$.

3. Membantu implementasi pengembangan sistem untuk pengembangan ERP terutama fungsi bisnis HRD/GA.

\section{PENUTUP}

\section{Kesimpulan}

Berdasarkan hasil penelitian mengenai Perancangan Enterprise Resource Planning (ERP) untuk Menunjang Fungsi Bisnis di PT. SELECRIX dapat diambil kesimpulan yaitu Perancangan ERP yang dihasilkan lebih menitikberatkan kepada fungsi bisnis tata kelola sumber daya manusia di PT. SELECTRIX dikarenakan tata kelola sumber daya manusia di PT SELECTRIX masih manual dengan menggunakan aplikasi one processing.

\section{Saran}

Berdasarkan dari penelitian yang telah dilakukan, penulis merasa masih banyak kekurangan dalam penelitian ini. Berikut adalah beberapa saran yang dapat penulis sampaikan untuk pengembangan Perancangan Enterprise Resource Planning (ERP) untuk Menunjang Fungsi Bisnis di PT. SELECRIX di masa yang akan datang :
1. Perancangan ini diharapkan dapat diimplementasikan ke dalam Sistem Informasi yang menjadi bagian dari ERP secara nyata.

2. Perancangan ini hendaknya dikembangkan sesuai kebutuhan fungsi bisnis di perusahaan di masa yang akan datang.

\section{DAFTAR PUSTAKA}

[1]. Al-Bahra bin ladjamudin. 2013. Analisis dan Desain Sistem Informasi. Yogyakarta : Graha Ilmu

[2]. Adi Nugroho 2005. Analisis dan perancangan sistem informasi dengan metodologi berorientasi objek. Informatika. Bandung

[3]. Abdul Kadir. 2002. Pengenalan Sistem Informasi. Andi. Yogyakarta

[4]. James A. O'Brien, and George Marakas. 2007. Management Information Systems with MISource, 8th ed. Boston, MA: McGraw-Hill, Inc

[5]. Fui, Fiona., Nah, Hoon. 2002. Enterprise Resource Planning Solutions \& Management. IRM Press.

[6]. Monk, Ellen., Wagner, Bret. 2013. Concepts In Enterprise Resource Planning Fourth Edition. Course Technology.

[7]. S.Pressman.Roger. 2012. Rekayasa Perangkat Lunak Pendekatan Praktisi. Yogyakarta : Andi Publisher.

[8]. Setia, Bambang. 2003. Metodologi Penelitian Berorientasi Objek. Bandung : Informatika.

[9]. Indrajit, E. 2004. Dari MRP ke ERP. APTIKOM

[10].Wijaya F Santo \& Darudiarto Suparto. 2009. ERP (Enterprise Resource Planning) Solusi Bisnis. Yogyakarta : Graha Ilmu

[11].A.S. Rosa dan M. Shalahuddin, 2013, Rekayasa Perangkat Lunak Terstruktur dan Berorientasi Objek. Bandung: Informatika.

[12].Fatansyah, 2007, Buku Teks Komputer Basis Data. Bandung: Informatika. 